\title{
Aufsätze
}

Bettina Westle, Christian Begemann and Astrid Rütter

\section{The "Wahl-O-Mat" in the course of the German Federal Election 2013 - Effects of a German VAA on users' election-relevant political knowledge}

\section{Summary}

Ideally, voters should be fully informed about party positions on important political issues and vote for the political party, which suits their own interests and ideas best. Yet, in general, political knowledge is quite low among the public. Moreover it is distributed unequally among social segments. Therefore the legitimacy of representative democracy is challenged.

The German "Wahl-O-Mat" aims at informing the electorate on party positions and at fostering "correct voting". During the campaign for the Bundestag election 2013 the "Wahl-O-Mat" was used more than 10 million times.

In this article we ask in how far the "Wahl-O-Mat" contributes to voters' political knowledge on parties' positions on selected political issues. Our analysis is based on an online pre-experimental design conducted two weeks before the election. The main results show that using the "Wahl-O-Mat" increases knowledge on party positions, but only to a small degree. Besides improvements of information levels, the number of "don't know"-answers also rises. The degree to which individuals are able to learn depends strongly on pre-existing knowledge levels. The latter in turn are determined by motivation and resources. 


\section{Content}

1. Introduction 390

a) The relevance of issue-knowledge for voting 391

b) Political knowledge in Germany 392

c) Function, operating mode and effects of Vote Advice Applications 394

d) Effects of VAA-usage: empirical evidence 396

e) Hypotheses 398

2. Database and research design 400

3. Results 403

a) Objective knowledge change by VAA-usage 403

b) Socio-demographic and motivational factors influencing knowledge an learning via Wahl-O-Mat 408

c) Subjective knowledge gain by VAA-usage 413

4. Conclusion 415

\section{Introduction}

Political knowledge is the basis of political participation in accordance with citizens' specific interests. Yet, gathering this knowledge can be a demanding task, as information can be found widespread across different sources. Publications by parties are usually very dense and informative but often hard to understand. For this reason mass media are the most important opportunity structure for political information (Delli Carpini/Keeter 1996; Maurer 2009). But the selection and presentation of topics follows the logic of mass media, not necessarily the needs of its readers. Reports often focus on negative aspects, do not cover all aspects of a topic (Kepplinger/Weißbecker 1991; Esser 1999; Maier 2009) and can be influenced by its editors' personal political ideas (Quiring 2004; Hagen 2005). Thus, often mass media do not sufficiently inform the voter about election-relevant issues. The internet greatly facilitates the publishing of information, leading to a vast number of contributors in an uncontrollable context. This makes searching for relevant and reliable information more complicated, even for politically interested and educated citizens, and can lead to information overflow and uncertainty (Toffler 1971; Beck 2003).

At this point Voting Advice Applications (VAAs) come into play. They aim at structuring and simplifying political information regarding political ideas of competing parties in the forefront of elections and have reached an overwhelming po- 
pularity in recent years, especially in European countries (Garzia/Marschall 2012; Marschall/Garzia 2014). The Federal Agency for Civic Education (Bundeszentrale für politische Bildung) issues the German "Wahl-O-Mat" in cooperation with political scientists, hereby securing quality and correctness of any information offered.

Our article tries to analyze how successfully the German VAA is able to inform users on political party positions before the German Federal Election in 2013. We will analyze its effects on learning about political issues regarding the five most relevant parties.

\section{a) The relevance of issue-knowledge for voting}

Even in political science no general agreement exists about what constitutes sufficient political knowledge, which aspects are more and which are less important for a rational voting decision. Berelson et al. state: "The democratic citizen is expected to be well informed about affairs. He is supposed to know what the issues are, what their history is, what the relevant facts are, what alternatives are proposed, what the party stands for, what the likely consequences are. By such standards the voter falls short" (1954: 308). A widely accepted, though briefer summary of necessary political knowledge (not restricted to the act of voting), is delivered by Delli Carpini and Keeter: "the rules of the game, the substances of politics, and the people and parties" (1996: 65). Despite the important role of political knowledge, this research field is rather underdeveloped in Germany in comparison with e.g. the USA (Vetter/Maier 2005; Westle 2005, 2009 a, 2012; Maier 2009; Maier et al. 2009).

The well-known social psychological approach models the voter's decision as a result of party identification, attitudes towards political issues and candidate preference (Campbell et al. 1954, 1960; Schoen/Weins 2014). The component "issues" consists of preferences concerning controversial policies (position issues) and evaluations of party competences regarding consensual goals in different policy areas (valence issues). As traditional social cleavages are declining, long-term determinants of voting, such as party identification, are also decreasing. Therefore citizens' vote choice is more and more based on prevailing issue preferences and the perceived proximity of voters' and parties' positions (Schmitt-Beck/Weick 2001; Rudi 2011). Prerequisites for rational voting based on specific issues are clear and distinguishable issue positions of parties, as well as of voters and moreover on the part of the voter a profound knowledge about the party positions concerning the issues at hand - at the least concerning the topics which are most im- 
portant to him/her personally (Downs 1957; Butler/Stokes 1969; Nie et al. 1996; Arzheimer/Schmitt 2014). Voting based on issue preferences relies especially on factual correct information about party positions, because wrong information can easily lead to voting decisions contradicting the actual interests of the voter. Miscellaneous results show regularly a substantive amount of citizens who did not vote "correctly" according to their own interest, because they held wrong assumptions about party positions. On the macro level this indicates that the overall outcome of elections would have been different, if people were fully and correctly informed about party positions (Bartels 1996; Lau/Redlawsk 1997; Althaus 1998; Lau et al. 2008; Bhatti 2010; Kraft 2012; Rudi/Schoen 2013). Furthermore, prospective voting, in contrast to retrospective sanctioning or rewarding voting, needs a reliable basis of correct information, which cannot be gained by experience the voters have with past governments, but has to be delivered by parties and mass media.

\section{b) Political knowledge in Germany}

According to the sparse empirical evidence available, the level of knowledge about parties' political positions on various issues in Germany seems to be rather low in general. Westle (2011) analyzed the answers interviewees gave regarding the five biggest German parties and their positions on four different issues and found percentages of correct answers regularly lying at only $50-60 \%$, in spite of a chance of guessing the correct answer of $50 \%$ per item. Only knowledge on the biggest party CDU is a little higher with more than $60 \%$ correct answers in most cases. Also Vetter and Maier (2005) observed knowledge levels of mainly about $50 \%$ correct answers, some items showing much higher values (usage of nuclear energy in case of the German Green Party) or much lower (around 20\%) for a less established party (the former PDS, now "The Left"). Knowledge about party positions on issues is strongly dependent on the issue itself as well as the respective party for which the position is to be identified. While smaller parties with a strong issue ownership (e.g. the Green Party with nuclear energy) and the leading parties can reach $80 \%$ or $90 \%$ percent correct answers regarding widely discussed issues, the picture is rather bleak for non prominent or very new issues and for small parties without strong issue ownership. In these cases the level of correct knowledge often ranges below 50\%. Before the German national election 2005 only $29 \%$ of the participants could give the right answer regarding all four position items for the German social-democratic party (SPD), which was still the highest score reached, compared to the other parties (Westle 2009 a). 
Maier et al. (2009) analyzed a broad variety of political knowledge items stemming from different surveys in Germany in a secondary analysis. They found that the level of information about issues is comparably low with a median of only $30 \%$ correct answers across the whole time period (since 1949), while knowledge about other political aspects (e.g. institutions, processes, actors) ranges much higher. Subjective knowledge (giving a substantial answer irrespective of it being true or false, instead of using the "don't know"-option) is a lot higher (Vetter/ Maier 2005; Westle 2005, 2009 a). This indicates that there is a large proportion of people, who believe false information about party positions. Thus, many citizens might base their vote choice on wrong assumptions.

Knowledge on public affairs and political knowledge in particular is distributed unequally between different groups of society. The individual knowledge level depends on the individual abilities and resources, motivation and social opportunity structures (Luskin 1990; Bennett 1996; Delli Carpini/Keeter 1996). The mass media are the most important opportunity structure for acquiring knowledge on public affairs. In contrast to American structures, in Germany mass media are easily accessible for everybody. Yet the extent to which they are actually used as a source for (political) information depends on various individual factors. Individuals with a higher educational level resp. a higher socioeconomic status, profit more strongly from mass media information flow. This has been shown for traditional mass media as well as for web-based information sources (Tichenor et al. 1970; Kuklinski et al. 2001; Otto/Kutscher 2004; Jerit et al. 2006). Further parameters are the individual's interest in politics and the resulting a priori level of political knowledge. For Germany Westle (2012) identified positive effects on individual political knowledge levels by education, income, interest in politics, and politically motivated media usage and found differences between people living in Germany with and without a Turkish immigration background as well (Westle 2011). Furthermore women still show less political knowledge than men. ${ }^{1}$ These results indicate that knowledge inequalities in Germany follow a socio-structural pattern leading to systematic disadvantages for certain social groups or strata. If members of such social groups are systematically less informed about politics than members of other social groups, citizens belonging to these groups will be much less capable of casting a vote according to their interests and preferences. Furthermore, individuals with lower levels of political knowledge are less in-

1 This gender gap in knowledge supposedly originates from less political socialization and a less political lifestyle of women on the one hand and is based on a more cautious response behavior of females when it comes to questions on political knowledge on the other hand (Westle $2009 \mathrm{~b}$; Mondak/Anderson 2004). 
clined to participate politically (Schoen 2005; Westle 2011, 2012). In such cases the needs and interests of some social groups are not communicated to the political elites and therefore will not be considered in political decision making. Additionally, if elected politicians do not represent the entire electorate but only those groups which are consistently better informed, knowledge inequalities might even result in an enduring exclusion of certain social strata from the political process over time, which challenges the legitimacy of representative democracy.

\section{c) Function, operating mode and effects of Vote Advice Applications}

Vote Advice Applications (VAAs) have been constructed to encourage citizens' political education by enhancing political knowledge on parties' positions on various issues. To achieve these aims, they directly provide information. Additionally, it is hoped to motivate users to seek further information on their own (Ruusurvita/Rosema 2009; Garzia 2010; Marschall/Schmidt 2010; Marschall/Garzia 2014). VAAs are meant to simplify and structure vast amounts of political information and are therefore especially of interest to citizens living in multi-party systems, as e.g. in European societies. In the USA, VAAs have been published, but are not equally widespread. As Garzia and Marschall found in 2012 there was at least one VAA employed in 25 of 27 countries of the European Union (excluding Croatia which joined the EU 2013) (Garzia/Marschall 2012; Marschall/Garzia 2014). Altogether they counted 40 different versions with varying features. The most famous "StemWijzer" of the Netherlands might have reached up to $38 \%$ of the electorate (4.9 million advices) in 2012 (Garzia/Marschall 2012); or even up to $52 \%$ relating the amount of users to the turnout rate, rather than to the whole electorate (Marschall/Garzia 2014). The German Wahl-O-Mat is a licensed spinoff of the Dutch VAA StemWijzer. In Germany it was provided in the run-up to the national election in 2002 for the first time, by the Federal Agency for Civic Education (Bundeszentrale für politische Bildung). It nearly doubled its usage from 6.7 million advices given in 2009 to about 13.3 million before the national election in 2013 , which adds up to $21.5 \%$ of the electorate. ${ }^{23}$

The underlying principle of all VAAs is to compare the preferences of the voter regarding selected policy-options with the positions of the competing parties. Ba-

2 www.wahl-o-mat.de/bundestagswahl2013/popup_faq.php\#qe11, last access 6.24.2014.

3 A system is installed to ensure that accessing devices are counted only once, but there is probably still an amount of users who use the VAA multiple times via different devices or via blocking cookies from its website, as well as people who use the VAA through the same device multiple times. Besides there might be also VAA users who are not even entitled to vote. 
sed on the proximity of the answers to party positions a ranking is computed that informs the voter about the congruence of his opinion with the parties' positions. In the case of the German VAA the formulation of statements on policy-options and the selection of issues are carried out by a workshop of young adults and first-time voters, who in turn are supervised by political scientists and experts. This method reflects the initial orientation of the Wahl-O-Mat aiming at young and first time voters as its target audience. Afterwards the chairmen of the accredited political parties are asked to state their position regarding these statements, taking a positive, negative or neutral stance (which is usually conveyed by an authorized party member). For the final version 38 statements are selected, which are required to cover a wide range of important topics and should be sufficiently controversial in order to clarify the distinctness of the political parties. The Wahl-O-Mat is accessible 2-4 weeks in advance to an election. To this day it has been used for national, regional as well as European elections. The Wahl-O-Mat calculates the distances between the user's position and the parties' positions. At first the user is asked about his/her individual opinion on the 38 statements. Then the user may choose up to 8 parties he/she would like his/her opinion to be compared to and furthermore mark issues especially important to her/him, which are double-counted in computing the degree of congruencies. Results are displayed in percentages of congruence between the user's opinion and each of the 8 parties' positions. Additionally the user may compare positions for every single statement directly and moreover learn through which arguments the parties justify their positions. Although the Wahl-O-Mat only compares up to 8 parties simultaneously, the user is able to cover all accredited parties by repeating the calculation. The Wahl-O-Mat is published on the website of the Federal Agency for Civic Education, where a wide range of background information on political parties, the electoral system and political issues complements the VAA. ${ }^{4}$

Compared to the German electorate in general, the online population consists of more male persons, is somewhat younger, higher educated and shows a somewhat higher political interest. Wahl-O-Mat users are still a little younger, higher educated and characterized by a stronger interest in politics and rather stable party identifications than the general German online population (Marschall/Schmidt 2010). Especially the latter suggests that German VAA-users are not necessarily undecided, but rather use the Wahl-O-Mat in order to confirm their party preference.

4 http://www.bpb.de/politik/wahlen/wahl-o-mat/166945/wie-funktioniert-der-wahl-o-mat, last access 10.20.2014. 
One disputable aspect about VAAs is the absence of valence issues in which all parties take the same position but attribute a different importance or propose different means to reach the same goal. Even if voters can weight issues as more or less important, the parties often do not have this option, as is the case in the German application (Garzia 2010). This may be problematic for smaller, specialized parties with a strong issue-ownership. Critics of the state of VAAs also focus on the process of statement selection. Competing VAAs that are employed in the same election period can produce very different vote advices for the same voters, if the statements are exchanged (Kleinnijenhuis/Krouwel 2007; Walgrave et al. 2009). Because VAAs can have effects on voting decisions, Ladner et al. (2010) demand that political scientists should be involved more deeply in their development, as well as in research on VAAs and further suggest that these ought to be constructed as transparently as possible.

\section{d) Effects of VAA-usage: empirical evidence}

In recent years a body of research has developed on the effects of VAAs usage in Europe, focusing mostly on user's political behavior. The use of VAAs has been shown to increase the self-predicted participation in elections. The degree of this effect varies strongly by country and study design (Mykkänen/Moring 2007; Ruusurvita/Rosema 2009; Marschall/Schmidt 2010; Marschall/Schultze 2012; Garzia et al. 2014; see the overview in Garzia/Marschall 2012). Effects on vote choice are only minor. Only a small proportion of users is willing to change their voting choice according to the voting advice given (Marschall 2005; Ladner et al. 2010; Andreadis/Wall 2014; Alvarez et al. 2014; see the overview in Garzia/ Marschall 2012). Furthermore these effects depend on individual characteristics such as the number of parties the user feels sympathy for (Wall et al. 2014) and political knowledge levels (Pianzola 2011).

Regarding information effects researchers may be faced with the problem of users' motivation, as the latter may not be interested in getting a broad set of new information after all. According to van de Pol et al. (2014) the biggest group of VAA-users is formed by highly interested "checkers", who already know which party they will vote for and use VAAs for entertainment or in order to confirm their vote choice. Most users in need of information and advice are "doubters". However, due to their low level of political interest, supposedly they will not profit strongly from VAA-use in terms of knowledge gain. According to the findings of Marschall (2011) over 50\% of the politically interested respondents intended to confirm their planned voting decision, $16 \%$ looked for vote advice and only $7 \%$ 
stated that they wanted to get informed about party positions. The latter figure is also true for politically uninterested respondents, all the while $50 \%$ of them searched for vote advice. These results are in line with psychological concepts of avoiding cognitive dissonance and of confirmation bias: People tend to select information which confirms their beliefs and try to avoid or to argue against disconfirming arguments (Festinger 1989; Taber/Lodge 2006).

Up to date the direct effects on political knowledge have rarely been analyzed. To our knowledge only one study exists that searched for influences of VAA-usage on political knowledge systematically: Schultze (2014) ${ }^{5}$ analyzed effects of the German Wahl-O-Mat on political knowledge before the German Federal Election in 2009. He used an online sample from the German Longitudinal Election Study (GLES), representative for the general online population in Germany. The survey included three items on the positions of the five most relevant parties' in identical wording as used in the German VAA and an additional question whether participants of the GLES had used the Wahl-O-Mat before participating in the survey. Bivariately he found a considerably higher level of knowledge for users of the VAA. Multivariately he employed a non-recursive path model that represented the influence of VAA-use on knowledge about party positions. Controlling for age, education, gender and political interest he found significant moderate positive effects of VAA-use on political knowledge on a par with the influence of political interest.

The aspect of political knowledge is gaining relevance in elections continuously. The growing demand for up-to-date information about parties prior to every election, which accompanies the trend of voting based on short-term factors instead of party affiliation (Franklin et al. 1992; Dalton/Wattenberg 2000; Garzia 2010; Garzia/Marschall 2012), along with the general accessibility of VAAs explains the growing popularity of these online tools across Europe (Walgrave et al. 2008; Garzia 2010; Garzia/Marschall 2012). VAAs advertise their ability to deliver specialised information on parties' positions in a format easy to digest, hence reducing the cost of gathering and processing information. The presentation of information in form of an overview structured by the specific interests of the user should be more accessible than party-manifestos and newspaper articles or TVnews. However, does the VAA in Germany - the Wahl-O-Mat - fulfil its promise of civic education? Furthermore, does the presumed easy accessibility of information through this application reduce social inequality of political knowledge or

5 A German version of this article was published in Zeitschrift für Politikwissenschaft (ZPol) $2012(3), 367-391$. 
does the potential learning effect by using the Wahl-O-Mat itself depend on individual socioeconomic parameters?

\section{e) Hypotheses}

For our analysis we expect that VAA-usage will affect objective political knowledge on party positions positively in the aggregate (according to the findings of Schultze 2014). As the Wahl-O-Mat presents party positions in a structured and condensed way, the user should gain at least some knowledge by using it. For the time being, it is unreasonable to expect it could have an adverse effect.

H1: Aggregate levels of knowledge after Wahl-O-Mat-use are higher than before.

Yet, the question remains how much the individual user will learn. As was stated previously, in spite of the easy accessibility of the Wahl-O-Mat, we assume that certain individual prerequisites affect the individual profit.

$\mathrm{H} 2$ : The higher the level of the user's political knowledge prior to using the VAA, the higher the additional gain in knowledge through VAA-usage.

This assumption mainly rests on earlier observations that the cognitive acquisition of new facts is facilitated if they can be integrated into already existing cognitive structures (Ausubel 2000).

H3: The higher the users' levels of political motivation, the greater are not only their pre-VAA levels of knowledge, but also their success in learning.

Indicators of political motivation are, for example, political interest and reception of political media. Political involvement should foster a more intensive and more competent use of the VAA and therefore result in larger gains in knowledge. Furthermore, individuals who use information structures, such as media or their social circle, as sources for political information more often, are motivated stronger and hence are probably more sophisticated in politics. We therefore assume that interest in politics and politically motivated usage of information sources fosters objective learning.

H4: Individuals with an existing party identification will learn more by WahlO-Mat-usage, yet, this gain will be limited to the party they feel close to for the most part.

Party identification can be seen as an indicator for political involvement as well and therefore should exert a positive effect on learning. But as voters often behave as "cognitive misers" (Fiske/Taylor 1991; Stroh 1995) learning processes will probably focus on their preferred party. Persons without a prior party affiliation are those most in need of a broad knowledge about differing party positions in or- 
der to vote for the appropriate party and should be eager to gain knowledge by using VAAs. However, if the lack of party identification represents alienation from the political process or a general lack of political interest, probably such users will be less inclined to learn something new.

H5: Individuals holding a specific opinion on a certain political issue will learn more about this topic by VAA-usage than users without such a pre-existing opinion.

Participants should be more interested in learning about parties' positions on issues they express an opinion on, as having an opinion on something indicates interest in the specific topic.

Moreover, it is well known that certain socio-demographic factors are correlated with political knowledge and with the usage of informational opportunity structures. Therefore, in the following we try to transfer these known determinants of knowledge to assumptions about learning.

H6: Higher levels of general education and job education lead to increased knowledge gains.

Cognitive abilities constitute the most general basis for knowledge and learning. Since we cannot measure intelligence or cognitive abilities directly, we use the level of education as a proxy. Additionally, higher education usually represents a stronger political socialization. The latter is also the case for job education.

H7: Income correlates positively with learning.

On the one hand, income is often based on education. Furthermore, income is a proxy for material resources, which may facilitate the competent use of media and online tools in return.

H8: Younger users will learn more from employing VAAs than older users. The effect of age is difficult to hypothesize. While users of higher age are more experienced and more knowledgeable in politics in general, younger persons will be more familiar with online-applications. Furthermore the Wahl-O-Mat was designed to appeal to younger and first time voters especially. If it succeeds in achieving this goal, younger users will presumably feel more motivated to participate and for this reason might gain more knowledge.

H9: Male users will learn more by VAA-usage than females.

This assumption rests on the observation of higher levels of political knowledge among males in comparison to females. This result is often noticeable even after controlling for education, due to a lower level of political interest among women, which corresponds to a lack of political socialization or a less political lifestyle. Thus, generally women seem to be less motivated to engage in politics. 
Finally, as subjective competence is an important determinant of political participation, we also analyze the impact of VAA-usage on subjective learning. Earlier research has conceptualized interest in politics, objective political knowledge and subjective political competence to be strongly circularly related (e.g. Delli Carpini/Keeter 1996). For this reason we assume that subjective competence affects objective learning by Wahl-O-Mat-usage by increasing the users' motivation to gain knowledge:

H10: More subjectively competent users will learn more through VAA-usage. Furthermore, because we assume that VAA-usage results in an objective knowledge gain, we also expect an increase in subjective knowledge to occur:

H11: Using the Wahl-O-Mat has positive effects on subjective learning corresponding to the actual knowledge gain.

Indeed, if this is the case, it can help generate an understanding of why VAAs would also have a positive indirect effect on objective learning. If a participant believes that the usage of the Wahl-O-Mat has increased his/her political knowledge, he/she might be motivated even further to gain additional knowledge via other sources. However, we will not go into any more detail regarding individual determinants of subjective appraisement of learning by VAAs in this article.

\section{Database and research design}

Our data originate from an online-panel, collected by the LINK institute in Frankfurt am Main, Germany, shortly before the national election in 2013. By the application of quotas our sample approximately matches the basic population of private German internet users between 18 and 69 years of age, who use the internet at least once a week, regarding age, gender and education. Additionally we limited the sample to individuals eligible to vote at the 2013 national election. Our analysis for this article is based on a group of 150 respondents. ${ }^{6}$ Such a small sample size is not unusual for experimental designs. However it does limit the possibility of strong differentiations within the sample as well as of multivariate analyses.

The sample consists of $55 \%$ male and $45 \%$ female participants. The biggest group is between 40 and 49 years of age and completed intermediate secondary education. Half of respondents earn less than 2,600 Euro per month as a household. About $80 \%$ of the sample live in western Germany. On a scale from $1=$ not at all to $5=$ very much, the average subjective interest in politics lies at about 3 and displays a medium strong interest. $85 \%$ declare to identify with one of the Ger-

6 This group is part of a larger project containing various experimental designs. Due to financing reasons we were not able to increase the sample size. 
man political parties, mostly with the larger ones CDU and SPD, and with a moderate to rather strong intensity. The distribution of age and gender in our sample corresponds to the general online population ((N)Onliner-Atlas 2014). ${ }^{7}$ Regarding education our sample shows a small bias towards the middle category, and concerning income of household towards the higher level incomes. As the population of Wahl-O-Mat-users generally tends to be higher educated than the average internet user, this bias is not necessarily disadvantageous. Concerning political attitudes, interest in politics and intensity of party identification, the distributions in our study on average are the same as in the German Longitudinal Election Study 2013. Although the exact percentages of party identifications differ slightly, the sequence of identification is identical, with most respondents showing party identification with $\mathrm{CDU}^{8}$ (see Appendix table A1).

In order to examine the effect VAA-usage exerts on political knowledge in respect to party positions we developed a pre-experimental one-group pretest-posttest study design (Campbell/Stanley 1966). As our sample is rather small we did not divide it into a control group and a treatment group. Instead, we chose this methodological option which allows us to retain a higher number of cases and thus a better basis for multivariate analysis. The survey takes about twenty minutes and respondents were questioned right before and after the VAA-treatment. For this reason, it is improbable that participants were systematically exposed to distorting influences of third variables and a causal link between Wahl-O-Matusage and learning effects should be measurable.

At first we measured respondents' own position on 6 contemporary political issues and their knowledge of the positions the five most important parties take on the same issues. The scale for answering offers the options "rather opposed", "rather in favor", "no clear position" and additionally a "don't know"-option. Then, respondents were requested to use the Wahl-O-Mat and come back afterwards to complete the survey. After using the VAA respondents were asked about their knowledge on these party positions once more. The questionnaire also includes an item on the respondents' subjective estimation of their knowledge gain through the VAA, as well as various items on political attitudes and media reception. The 6 issues we employed were also included in the Wahl-O-Mat-application and cover a wide range of different topics: the implementation of a statutory general minimum wage, the retention of telecommunication data, the legal equalization of homosexual civil partnerships regarding adoption rights, the increase of the top

7 Study D21-Digital-Index / (N)ONLINER Atlas 2014, TNS Infratest / Initiative D21.

8 GLES, study number ZA5721, weighted results. 
rate of income tax, the implementation of Eurobonds and the quota for gender representation at the management level of larger companies. Although referring to the same issues, wording of the statements in the Wahl-O-Mat differ slightly from our items, which may impede the recognition of issues in the second part of our questionnaire. Additionally, in contrast to our design, the Wahl-O-Mat includes a "skip thesis"-button. However, this minor discrepancy should not affect the measurement of gain in knowledge, as party positions are displayed for skipped statements anyway and information on these issues is available, too. The text of all Wahl-O-Mat-statements (figure A1), the wording of our items (figure A2), and a display of correct party positions according to the Wahl-O-Mat (figure A3) can be found in the attachment of this article.

Our hypothesis states that by using the Wahl-O-Mat a learning process occurs which causes an improvement of knowledge on party positions at the second point of measurement, operationalized by the amount of right answers. In order to receive a complete picture of the change in knowledge via Wahl-O-Mat-usage, we also observe changes in wrong and "don't know"-answers. Lower knowledge levels resp. more wrong or "don't know"-answers following the use of the VAA could indicate that respondents were overwhelmed and confused by the mass of information offered by the Wahl-O-Mat. Yet, it might also be a symptom of respondents' exhaustion or impatience, being expressed in speeding behavior and striving to finish the interview as quickly as possible. Moreover, increases of "don't know"-answers can also represent a decrease of subjective, but false knowledge: If a respondent becomes aware of a lack in knowledge he/she was not aware of prior to using the VAA, learning has also occurred. Additionally, although the correct information may not be present in the participant's mind at the time, becoming aware of a lack in knowledge can motivate the user to seek further information. In this case the Wahl-O-Mat would have at least fulfilled its purpose in part.

We do not know whether our participants ever used the Wahl-O-Mat prior to our survey. Yet, in order to observe information effects caused by the VAA this is not problematic as data on initial knowledge levels were collected, before the respondents used the Wahl-O-Mat in the experimental stage, and later integrated into our analysis. Furthermore, our results cannot be applied to the general population of Wahl-O-Mat-users, since respondents did not utilize the application on their own initiative. As they were motivated by monetary incentives instead of intrinsic interest or need for information, they in sum will probably learn less than the "real" Wahl-O-Mat-user. 
The final methodological comment to be made here is that our assumptions can only be verified if there is no ceiling-effect. The potential range for learning in the context of our experimental design is determined by the number of party positions asked, in our case 30. If a participant has no knowledge at all, at the beginning the range of potential learning throughout the study equals 30 party positions. In contrast, if a participant knows all of these party positions before VAA-usage, we cannot measure any additional gain in knowledge and the potential range is 0 . Therefore beside indices counting the summarized change in correct, wrong and "don't know"-answers, we calculate an additional indicator for knowledge change, which accounts for the respondent's individual potential for improvement or deterioration. The index will be explained further below, when it is presented for the first time.

\section{Results}

\section{a) Objective knowledge change by VAA-usage}

The pre-VAA-knowledge (defined as correct answers) on six issues regarding five parties varies between $14 \%$ and $84 \%$, with 10 party-positions in the lower range of up to $40 \%$ of respondents giving correct answers, 8 between $41 \%$ and $60 \%$ and 12 between $61 \%$ and $84 \%$ correct answers. These differences show a satisfactory range with sufficient room for change of knowledge levels in both directions (table 1).

Table 1: Pre-Wahl-O-Mat knowledge: single items

\begin{tabular}{|l|c|c|c|c|c|}
\hline $\begin{array}{l}\mathrm{n}=150 \\
\text { percentages }\end{array}$ & CDU/CSU & FDP & SPD & Green Party & The Left \\
\hline minimum wage & 54.0 & 58.7 & 84.0 & 65.3 & 72.7 \\
\hline data retention & 58.7 & 32.7 & 14.0 & 56.0 & 58.0 \\
\hline $\begin{array}{l}\text { same-sex partner-ships: } \\
\text { joint adoption }\end{array}$ & 69.1 & 38.0 & 64.0 & 65.3 & 35.3 \\
\hline top rate income tax & 72.0 & 65.3 & 72.0 & 58.7 & 64.7 \\
\hline eurobonds & 32.7 & 33.3 & 34.7 & 23.3 & 18.7 \\
\hline gender quota & 37.3 & 46.0 & 61.3 & 71.3 & 47.3 \\
\hline
\end{tabular}

Summarizing respondents' answers across the parties as shown in table 2 a reveals decreases of wrong answers in respect to each party, as one would hope for. Yet often also strong increases of "don't know"-answers can be found, which 
then results in only moderate overall increases of correct answers for each party. The Green Party ${ }^{9}$ is an exception where a minimal decrease occurs. Changing the perspective from the parties to the topics (table $2 \mathrm{~b}$ ) brings a less clear picture since "don't know"-answers rise in all cases except for the Eurobonds, wrong answers rise only regarding the retention of telecommunication data and the income tax, whereas correct answers increase only in regard to the rights of homosexual partnerships and the Eurobonds. Summarizing all 30 questions results in a very modest increase of correct answers from 15.64 to 15.95 and a slightly stronger increase in "don't know"-answers (7.63 to 8.18). The strongest observable change is a decrease in wrong answers (6.73 to 5.87). The substitution of wrong by "don't know"- answers could show that false knowledge was replaced by the awareness of having a lack of knowledge. This can be considered to be an improvement and is in line with empirical results hinting at a mobilizing effect by VAAs in respect to seeking further information (Garzia 2010; Ladner et al. 2010; Marschall/Schmidt 2010; Marschall/Schultze 2012). The increase of "don't know"-answers does not seem to be caused by "speeding" behaviour in the posttreatment condition, as correlations between the amount of non-substantial responses and processing time are marginal and not significant (table not shown).

Table 2 a: Changes in knowledge: countindices - aggregate level

\begin{tabular}{|l|c|c|c|c|c|c|c|c|c|r|}
\hline $\mathrm{n}=150$ & \multicolumn{10}{|c|}{ all 6 items per party } \\
\hline means & \multicolumn{2}{|c|}{ CDU/CSU } & \multicolumn{2}{|c|}{ FDP } & \multicolumn{2}{c|}{ SPD } & \multicolumn{2}{c|}{ Green Party } & \multicolumn{2}{|c|}{ The Left } \\
\hline VAA & pre & post & Pre & post & pre & post & Pre & post & pre & post \\
\hline don't know & 1.15 & 1.20 & 1.65 & 1.81 & 1.17 & 1.30 & 1.69 & 1.81 & 1.95 & 2.06 \\
\hline wrong & 1.61 & 1.48 & 1.61 & 1.40 & 1.53 & 1.31 & .91 & .83 & 1.08 & .85 \\
\hline correct & 3.23 & 3.32 & 2.74 & 2.79 & 3.30 & 3.39 & 3.40 & 3.37 & 2.97 & 3.09 \\
\hline
\end{tabular}

9 On the level of single knowledge items we find all possibilities of changes between pre- and postVAA-use: increases as well as decreases in right, in wrong and in "don't know"-answers. Moreover there is no regularity in knowledge change regarding neither the different parties nor the different issues or the distinctiveness of party positions about the issues (table not shown). 
Table 2 b: Changes in knowledge: countindices - aggregate level

\begin{tabular}{|c|c|c|c|c|c|c|c|c|c|c|c|c|}
\hline & \multicolumn{12}{|c|}{ all 5 parties per item } \\
\hline & \multicolumn{2}{|c|}{$\begin{array}{l}\text { minimum } \\
\text { wage }\end{array}$} & \multicolumn{2}{|c|}{$\begin{array}{c}\text { data } \\
\text { retention }\end{array}$} & \multicolumn{2}{|c|}{$\begin{array}{c}\text { same-sex } \\
\text { part- } \\
\text { nerships: } \\
\text { joint adop- } \\
\text { tion }\end{array}$} & \multicolumn{2}{|c|}{$\begin{array}{l}\text { top rate } \\
\text { income } \\
\operatorname{tax}\end{array}$} & \multicolumn{2}{|c|}{ eurobonds } & \multicolumn{2}{|c|}{$\begin{array}{l}\text { gender } \\
\text { quota }\end{array}$} \\
\hline means & pre & post & pre & post & pre & post & pre & post & pre & post & pre & post \\
\hline don't know & .77 & 1.13 & 1.42 & 1.48 & 1.23 & 1.25 & 1.19 & 1.21 & 1.91 & 1.78 & 1.12 & 1.33 \\
\hline wrong & .89 & .55 & 1.39 & 1.49 & 1.05 & .71 & .49 & .50 & 1.67 & 1.57 & 1.25 & 1.05 \\
\hline \multirow[t]{2}{*}{ correct } & 3.35 & 3.32 & 2.19 & 2.03 & 2.71 & 3.04 & 3.33 & 3.29 & 1.43 & 1.78 & 2.63 & 2.62 \\
\hline & \multicolumn{12}{|c|}{ all 5 parties and 6 items: 0 to 30} \\
\hline means & \multicolumn{6}{|c|}{ pre } & \multicolumn{6}{|c|}{ post } \\
\hline don't know & \multicolumn{6}{|c|}{7.63} & \multicolumn{6}{|c|}{8.18} \\
\hline wrong & \multicolumn{6}{|c|}{6.73} & \multicolumn{6}{|c|}{5.87} \\
\hline correct & \multicolumn{6}{|c|}{15.64} & \multicolumn{6}{|c|}{15.95} \\
\hline
\end{tabular}

Table 3 a summarizes the change in the amount of knowledge, by subtracting the pre-VAA-knowledge from the post-VAA-knowledge (both measured as correct answers) across all topics for each party and across all parties for each topic ${ }^{10} .{ }^{11}$ The indices on the single parties show nearly $40 \%$ of respondents remain without a change in their amount of knowledge and roughly $30 \%$ with a gain and also around $30 \%$ with a loss in their knowledge. Yet it must be acknowledged that the span of the most frequent change in the amount of knowledge covers merely one point in both directions of the scales from -6 to +6 .

Regarding the different policy topics the smallest change in the amount of knowledge can be observed on the tax issue, with $57 \%$ on the zero-point and the strongest change on the item regarding Eurobonds with only $24 \%$ on the zeropoint. With figures at about $38 \%$ and $37 \%$ the most frequent gains of knowledge occur referring to the right of homosexual partnerships and to Eurobonds. Howe-

10 This does not show the amount of individual improvement in correct answers between different items, but hints at the result of such exchanges. Thus, for example a value of 0 indicates neither an increase nor a decrease in the amount of knowledge. Still this does not necessarily indicate total stability in the answers before and after the VAA-usage either, because it could also result from item-specific different combinations of right and wrong answers before and after VAA-usage, in total this could yield the same amount of correct pre- and post-VAA answers.

11 For changes in knowledge of single items see appendix, table A2. 
ver, at the same time these issues also show relatively strong losses of knowledge (39\%), followed by the decrease in knowledge regarding the retention of data. Moreover, the means show that gains and losses of knowledge outweigh each other strongly with respect to the parties. Still, a slight rise of knowledge concerning each party's positions is observable, except regarding the Green Party. Also, knowledge on two topics in particular - the rights of homosexuals and the Eurobonds - increased. The summary-indices of all 30 items in Table $3 \mathrm{~b}$ show a somewhat stronger acquisition than a loss of knowledge, against the backdrop of a clear reduction in wrong, but not in "don't know"-answers. Concerning correct answers, a relative majority of $47.3 \%$ of respondents increased knowledge on party positions via VAA-usage, whereas $52.7 \%$ did not profit from it (consisting of $40 \%$ participants with less right answers than before and $12.7 \%$ with the same net amount of right answers). In sum on aggregate level we find small gains in knowledge, supporting hypothesis 1 .

Table 3 a: Changes in knowledge: Differences between countindices - individual level (correct answers: post-knowledge minus pre-knowledge)

\begin{tabular}{|c|c|c|c|c|c|c|c|}
\hline $\begin{array}{l}\text { per- } \\
\text { cent- } \\
\text { ages }\end{array}$ & $\mathrm{CDU} / \mathrm{CSU}$ & FDP & SPD & Green Party & The Left & & $\begin{array}{c}\text { all par- } \\
\text { ties and } \\
\text { items }\end{array}$ \\
\hline-1 to -6 & 28.0 & 30.0 & 28.0 & 32.7 & 28.7 & $\begin{array}{c}-1 \text { to } \\
-30\end{array}$ & 40.0 \\
\hline 0 & 38.7 & 39.3 & 38.7 & 37.3 & 37.3 & 0 & 12.7 \\
\hline 1 to 6 & 33.4 & 30.6 & 33.3 & 30.0 & 34.0 & 1 to 30 & 47.3 \\
\hline means & .09 & .05 & .09 & -.03 & .12 & & .31 \\
\hline & $\begin{array}{l}\text { minimum } \\
\text { wage }\end{array}$ & $\begin{array}{l}\text { data } \\
\text { retention }\end{array}$ & $\begin{array}{c}\text { same-sex } \\
\text { part- } \\
\text { nerships } \\
\text { joint adop- } \\
\text { tion }\end{array}$ & $\begin{array}{c}\text { top rate } \\
\text { income tax }\end{array}$ & Eurobonds & \multicolumn{2}{|c|}{ gender quota } \\
\hline-1 to -5 & 23.4 & 33.3 & 20.6 & 18.7 & 38.6 & \multicolumn{2}{|c|}{25.4} \\
\hline 0 & 47.3 & 40.0 & 40.7 & 56.7 & 24.0 & \multicolumn{2}{|c|}{48.0} \\
\hline 1 to 5 & 29.3 & 26.7 & 38.7 & 24.6 & 37.4 & \multicolumn{2}{|c|}{26.6} \\
\hline means & -.03 & -.16 & .33 & -.04 & .35 & \multicolumn{2}{|c|}{-.01} \\
\hline
\end{tabular}


Table 3 b: Changes in knowledge: Differences between countindices "all parties and items" - individual level (post-knowledge minus pre-knowledge; percentages)

\begin{tabular}{|c|c|c|c|}
\hline recoded for percentages & correct answers & wrong answers & $\begin{array}{c}\text { don't know } \\
\text { answers }\end{array}$ \\
\hline-1 to -30 & 40.0 & 48.0 & 39.4 \\
\hline 0 & 12.7 & 22.7 & 26.0 \\
\hline 1 to 30 & 47.3 & 29.3 & 34.8 \\
\hline unrecoded for means & .31 & -.86 & .55 \\
\hline
\end{tabular}

In the pre-VAA condition no respondent was able to answer correctly on all items, thus they all had a potential for a measurable gain of knowledge. In the following this potential for learning is defined as the largest gain possible in the amount of correct answers for every participant in the course of our experiment. It depends on the amount of correct answers reached in the first half of the experiment, prior to Wahl-O-Mat-usage, as follows: [maximum possible knowledge score pre Wahl-O-Mat] - [realized pre-Wahl-O-Mat knowledge score $]=$ [potential for learning by Wahl-O-Mat-usage]. The individual success in exhausting this design-determined learning potential is measured through division of the realized gain via Wahl-O-Mat-usage by the individual learning potential. The outcome ranges from 0 to 1: [(post Wahl-O-Mat knowledge score) - (pre Wahl-O-Mat knowledge score)] / [potential for learning by Wahl-O-Mat-usage]. ${ }^{12}$ Hence the measurement of achievement is always relative to the initial learning potential of each participant and ceiling effects are hereby avoided. The exhaustion of learning potential focuses on net gains, which means that additional correct answers can be counterbalanced by newly given wrong answers. Therefore we differentiate between participants who exhausted their learning potential positively and those who slipped into the negative spectrum, by giving less correct answers in the second run. For such participants who ended up with a negative net score we calculated the amount of "unlearning" relative to their potential of unlearning which is equal to the amount of correct answers given on the first run: ${ }^{13}[$ (post Wahl-O-Mat knowledge score) - (pre Wahl-O-Mat knowledge score)] / [pre

12 Assuming a respondent answered 20 items correctly of the 30 items available on party positions, his/her individual learning potential measurable by our experiment is [30]-[20] $=10$. If at the second point of measurement the respondent achieved 25 correct responses, he/she received a score of $[25-20] / 10=0.5$, which translates to $50 \%$ of the individual learning potential.

13 The 5 cases who did not answer to any item on the party positions correctly at the first point of measurement and consequently scored a 0 were excluded from the calculation in order to avoid division by 0 . 
Wahl-O-Mat knowledge score], with the indicator ranging from -1 to $0 .{ }^{14}$ The following calculations regarding exhaustion of design-determined learning potential were conducted separately for respondents with positive and negative net scores. Individuals whose knowledge levels did not change at all between the first and second point of measurement were excluded from this analysis. As mentioned before the group of participants who improved their score of correct answers has a share of $47.3 \%$ of the sample, $40.0 \%$ people deteriorated and for $12.3 \%$ of participants the net score did not change. On average, respondents who gained knowledge between the pre- and post-VAA condition received a value of 0.33 (exhaustion of $33 \%$ of individual learning potential). Similarly respondents who deteriorated exhausted their "unlearning" potential by $34 \%$ on average (-.34 on the scale; table not shown).

All in all, H1 is not rejected as knowledge gains through Wahl-O-Mat-usage actually did occur. However, this does not apply to the sample as a whole. The following paragraph examines possible factors affecting individual knowledge change by VAA-usage.

\section{b) Socio-demographic and motivational factors influencing knowledge and learning via Wahl-O-Mat}

Pre-VAA knowledge levels correlate significantly with gender and job education as socio-demographic parameters (table 4 a). Furthermore, if magazines, the radio or talks with friends are employed as sources for political information, the individual knowledge level is enhanced. Interest in politics and subjective information levels also correlate positively with pre-VAA knowledge. The correlates of postVAA knowledge levels are comparable to the pre-VAA condition, apart from an additional significant effect by general education and a very strong impact exerted by pre-VAA-knowledge. Net changes in correct answers (without considering respondents' potential for improvement or deterioration) do not correlate significantly with any of these factors. However, for exhaustion of learning and "unlearning" potential, correlates can be observed with objective pre-Wahl-O-Mat knowledge levels. Thus, H2 is completely supported by our findings. H3 is supported concerning interest in politics and regarding the negative link between exhaustion of "unlearning" potential and talking to friends about politics. As most of the demographic parameters are not significantly linked to learning by Wahl-

14 If a respondent in the pre-VAA condition achieved 20 correct responses but subsequently deteriorated to 10 in the post-VAA setting, he/she received a score of $[10-20] /[20]=-0.5$, exhausting $50 \%$ of the individual potential to deteriorate. 
The "Wahl-O-Mat" in the course of the German Federal Election 2013

\begin{tabular}{|c|c|c|c|c|c|c|c|c|}
\hline & 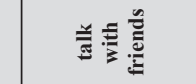 & 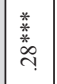 &  & $\stackrel{\infty}{i}$ & $\stackrel{\infty}{\longrightarrow}$ & a & $\exists$ & $\stackrel{*}{\stackrel{*}{i}}$ \\
\hline & $\frac{1}{\Xi}$ & a. & $\overrightarrow{0}$ & $\simeq$ & $?$ & iे & $?$ & $\stackrel{\infty}{\infty}$ \\
\hline & $\frac{1}{\partial}$ & $\approx$ & $\stackrel{0}{\circ}$ & 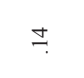 & \&. & के & $\stackrel{\infty}{\infty}$ & $\stackrel{p}{i}$ \\
\hline & @o & $=$ & $\fallingdotseq$ & $\exists$ & to & $\stackrel{\text { I }}{4}$ & $\stackrel{0}{0}$ & gे \\
\hline & 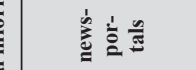 & $\fallingdotseq$ & $\fallingdotseq$ & 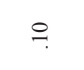 & 8 & t. & $\exists$ & $\stackrel{\infty}{i}$ \\
\hline & $\stackrel{1}{\dddot{2}}$ & 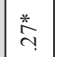 & $\stackrel{*}{\mathrm{H}}$ & $\bar{i}_{i}$ & $\%$ & t. & 8 & $\stackrel{?}{i}$ \\
\hline & 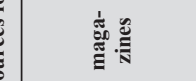 & 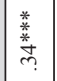 & 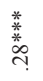 & ণ্ণ & के & $\vec{i}$ & ส & $\stackrel{n}{?}$ \\
\hline & 崖 & ฯి & 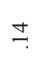 & $\approx$ & $\stackrel{\infty}{i}$ & ti & $\overbrace{i}$ & 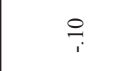 \\
\hline & $\geq$ & $\because$ & $\subsetneq$ & $\stackrel{0}{i}$ & $\approx$ & $\bar{p}_{i}$ & $\stackrel{\text { oे }}{\text { in }}$ & $\stackrel{\infty}{i}$ \\
\hline & 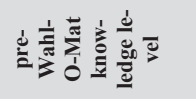 & . & 糙 & $\stackrel{ \pm}{i}$ & $\vec{i}$ & $\stackrel{\text { co }}{i}$ & $\stackrel{*}{\infty}$ & 菨 \\
\hline & 㝘音离离 & \begin{tabular}{|l|l} 
\\
絭 \\
f
\end{tabular} & 㢈 & $\tilde{o}$ & $\hat{i}$ & $\stackrel{\overbrace{}}{i}$ & $\stackrel{*}{\dagger}$ & $\stackrel{*}{*}$ \\
\hline & 离: & 豊 & 䱱 & $\overline{7}$ & $\stackrel{1}{\circ}$ & $\tilde{\sigma}$ & 䓠 & 䅈 \\
\hline & 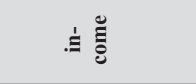 & (ุ) & $\stackrel{\infty}{\longrightarrow}$ & 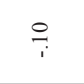 & $\fallingdotseq$ & $\tilde{\sigma}$ & $\stackrel{g}{i}$ & 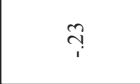 \\
\hline & 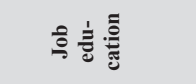 & $\stackrel{*}{\stackrel{*}{*}}$ & $\stackrel{*}{\stackrel{*}{\sim}}$ & $\stackrel{g}{i}$ & $\simeq$ & 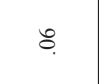 & $\stackrel{8}{8}$ & $\stackrel{0}{7}$ \\
\hline & 害高 & 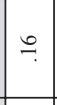 & $\stackrel{*}{\mathrm{*}}$ & $\bar{i}_{i}$ & $\stackrel{0}{0}$ & $\fallingdotseq$ & to & $\bar{\sigma}$ \\
\hline & 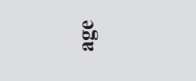 & $\rightarrow$ & $\because$ & $\approx$ & $\stackrel{0}{\circ}$ & 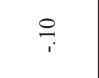 & $\stackrel{\varphi}{\dddot{1}}$ & ֻ. \\
\hline & 密 & $\underset{*}{*}$ & 莒 & $\underset{i}{\tilde{i}}$ & $\stackrel{0}{0}$ & ${ }_{i}$ & 7 & $\stackrel{?}{?}$ \\
\hline & & : & 营 & 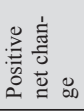 & 总产 & 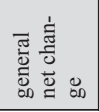 & 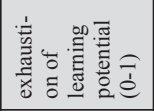 & 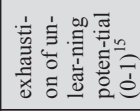 \\
\hline
\end{tabular}


O-Mat, H6, $\mathrm{H} 7$ and $\mathrm{H} 9$ are rejected. $\mathrm{H} 8$ is rejected as well, as age correlates negatively with exhaustion of "unlearning" potential, indicating that younger users loose more knowledge by VAA-usage than older users. On the other hand, H10 is supported, as subjective political competence clearly correlates with learning as well as "unlearning" by Wahl-O-mat-usage.

The multivariate models calculated to identify determinants of knowledge (table 4 b) contain the variables which bivariately correlate significantly with knowledge indices in table $4 \mathrm{a}$. Interest in politics still shows a very strong effect on preVAA knowledge. Furthermore pre-existing knowledge is determined by gender (positively for males), job education and the use of magazines resp. personal talks as sources for political education as well. In a multivariate model the post-VAA knowledge levels correlate strongly with the individual's pre-existing knowledge on party positions, as was expected, and is not significantly affected by interest in politics or demographic parameters. In how far the respondents utilize their potential for learning or "unlearning" also depends significantly on pre-Wahl-O-Mat knowledge, not on interest in politics. In general, the variance in knowledge before and after Wahl-O-Mat-usage, which can be explained by the models, is quite high. The explained variance of learning potential exhaustion lies at 12 resp. 37\%.

Controversial party positions on policy issues should be more important to voters, if they hold an opinion about the respective issues themselves. Table $5 \mathrm{a}$ shows that most respondents have a clear opinion on the topic of a statutory general minimum wage, which has been in public discussion for years, whereas the relatively new and complex issue of Eurobonds still needs time for more opinion formation. All topics are controversial among the respondents, with three items which are approved of and three which are rejected by majorities. This allows to test, whether holding an opinion shows systematic links to knowledge by itself and also whether approval or disapproval of a policy-proposal shows any systematic effect. As table $5 \mathrm{~b}$ illustrates, respondents who do not have an own opinion on an issue are on average the least knowledgeable on the party positions, expressing this in 5 out of the 6 cases. Hereby, H5 is supported. There is no systematic link between the own position for or against a topic and being in the majority or minority concerning this position on the one hand and pre-VAA knowledge on the other hand. Also, the average amount of knowledge does not change systematically after Wahl-O-Mat-usage. Thus, the personal position towards policies only seems to steer learning via Wahl-O-Mat marginally.

15 For tables $4 \mathrm{a}$ and $4 \mathrm{~b}$ the index "exhaustion of 'unlearning' potential" was recoded (0-1). Higher values mean an increase in unlearning. 
The "Wahl-O-Mat" in the course of the German Federal Election 2013

Tab 4 b: Determinants of knowledge and exhaustion of learning potential

\begin{tabular}{|l|c|c|c|c|}
\hline standardized beta & pre & post & $\begin{array}{c}\text { exhaustion of } \\
\text { learning } \\
\text { potential }\end{array}$ & $\begin{array}{c}\text { exhaustion of } \\
\text { unlearning } \\
\text { potential }\end{array}$ \\
\hline interest in politics & $.56^{* * *}$ & .12 & .06 & -.06 \\
\hline gender (female) & $-.16^{*}$ & -.06 & - & - \\
\hline age & - & - & - & -.21 \\
\hline education & - & .12 & - & - \\
\hline job education & $.15^{*}$ & -.07 & - & - \\
\hline magazines & $.17^{*}$ & -.04 & - & - \\
\hline radio & .01 & -.01 & - & -.19 \\
\hline talk with friends & $.21^{* *}$ & .05 & - & $-.52^{*}$ \\
\hline $\begin{array}{l}\text { pre Wahl-O-Mat know- } \\
\text { ledge }\end{array}$ & - & $.74 * * *$ & $.32 *$ & .11 \\
\hline subjective information & .01 & -.04 & .08 & .37 \\
\hline corr. $\mathrm{r}^{2}$ & .55 & .68 & .12 & - \\
\hline
\end{tabular}

*significant at $\mathrm{p}<0.05 ; * *$ significant at $\mathrm{p}<0.01 ; * * *$ significant at $\mathrm{p}<0.001$.

Due to the low number of respondents in our sample, especially in regard to the ones identifying with a smaller party, it is difficult to test our hypotheses concerning the relation between party identification and knowledge resp. learning. However, looking at the respondents without any party identification first, table 6 demonstrates that they indeed are the ones with the lowest overall knowledge in the beginning of the survey. They only show a modest increase in knowledge after using the Wahl-O-Mat but still learn more than identifiers of CDU and SPD. Learning effects for Green Party identifiers are comparable to individuals without party identification. Persons feeling close to FDP learn more than individuals without party identification. Yet, they do not learn the most about their identification party which might be caused by ceiling effects as they knew 5.25 out of six positions already before VAA-usage. For the partisans of the two larger parties a mechanism in the guise of "know your rival" seems to be at work, as before VAA-usage CDU/CSU identifiers know less about their party than about SPD and vice versa for SPD-identifiers. In the course of VAA-utilization SPD-identifiers learn most about SPD and The Left. Except from CDU-identifiers all groups gain knowledge on party positions by VAA-use. Yet, party identifiers do not systematically learn more than non-identifiers and also the assumed link between 
Bettina Westle, Christian Begemann and Astrid Rütter

Table 5 a: Issue-positions of respondents (pre Wahl-O-Mat)

\begin{tabular}{|l|c|c|c|c|c|c|}
\hline $\begin{array}{l}\text { per- } \\
\text { cent- } \\
\text { ages }\end{array}$ & $\begin{array}{c}\text { minimum } \\
\text { wage }\end{array}$ & $\begin{array}{c}\text { data } \\
\text { retention }\end{array}$ & $\begin{array}{c}\text { same-sex } \\
\text { partnerships: } \\
\text { joint adoption }\end{array}$ & $\begin{array}{c}\text { top rate } \\
\text { income tax }\end{array}$ & $\begin{array}{c}\text { eurobonds } \\
\text { quota }\end{array}$ \\
\hline undecided & 8.7 & 19.4 & 21.5 & 18.1 & 26.9 & 56.2 \\
\hline against & 12.8 & 61.1 & 26.2 & 22.4 & 52.4 \\
\hline for & 78.5 & 19.5 & 52.3 & 149 & 138 & 26.9 \\
\hline N & 149 & 144 & 130 & 145 \\
\hline
\end{tabular}

Table 5 b: Knowledge on issues dependent on own issue-position

\begin{tabular}{|c|c|c|c|c|c|c|c|c|c|c|c|c|}
\hline \multirow[t]{2}{*}{ Means } & \multicolumn{2}{|c|}{ minimum wage } & \multicolumn{2}{|c|}{$\begin{array}{c}\text { data } \\
\text { retention }\end{array}$} & \multicolumn{2}{|c|}{$\begin{array}{c}\text { same-sex } \\
\text { partnerships: } \\
\text { joint adoption }\end{array}$} & \multicolumn{2}{|c|}{$\begin{array}{c}\text { top rate } \\
\text { income tax }\end{array}$} & \multicolumn{2}{|c|}{ eurobonds } & \multicolumn{2}{|c|}{$\begin{array}{l}\text { gender } \\
\text { quota }\end{array}$} \\
\hline & pre & change & pre & change & pre & change & pre & change & pre & change & pre & change \\
\hline & $(0-6)$ & $(-6-6)$ & $(0-6)$ & $(-6-6)$ & $(0-6)$ & $(-6-6)$ & $(0-6)$ & $(-6-6)$ & $(0-6)$ & $(-6-6)$ & $(0-6)$ & $(-6-6)$ \\
\hline undecided & 3.08 & -.15 & 2.29 & -.46 & 2.31 & .22 & 3.32 & -.36 & 1.03 & .71 & 2.13 & .23 \\
\hline against & 4.11 & -.32 & 2.19 & .00 & 2.74 & .23 & 3.32 & -.13 & 1.66 & -.14 & 2.82 & .04 \\
\hline for & 3.27 & .03 & 2.32 & -.36 & 2.90 & .42 & 3.68 & .05 & 2.23 & -.64 & 2.97 & -.28 \\
\hline Eta & .19 & .09 & .04 & .13 & .15 & .06 & .10 & .09 & .22 & .14 & .21 & .13 \\
\hline $\mathrm{N}$ & \multicolumn{2}{|c|}{149} & \multicolumn{2}{|c|}{144} & \multicolumn{2}{|c|}{149} & \multicolumn{2}{|c|}{138} & \multicolumn{2}{|c|}{130} & \multicolumn{2}{|c|}{145} \\
\hline
\end{tabular}

Table 6: Knowledge on parties dependent on party-identification

\begin{tabular}{|c|c|c|c|c|c|c|c|c|c|c|c|c|c|}
\hline \multirow{2}{*}{\multicolumn{2}{|c|}{ Means }} & \multicolumn{2}{|c|}{$\mathrm{CDU} / \mathrm{CSU}$} & \multicolumn{2}{|c|}{ FDP } & \multicolumn{2}{|c|}{ SPD } & \multicolumn{2}{|c|}{ Green Party } & \multicolumn{2}{|c|}{ The Left } & \multicolumn{2}{|c|}{ all } \\
\hline & & \multirow{2}{*}{$\frac{\text { pre }}{(0-6)}$} & \multirow{2}{*}{$\frac{\text { change }}{(-6-6)}$} & \multirow{2}{*}{$\frac{\text { pre }}{(0-6)}$} & \multirow{2}{*}{$\frac{\text { change }}{(-6-6)}$} & \multirow{2}{*}{$\frac{\text { pre }}{(0-6)}$} & \multirow{2}{*}{$\begin{array}{l}\text { change } \\
(-6-6)\end{array}$} & \multirow{2}{*}{$\frac{\text { pre }}{(0-6)}$} & \multirow{2}{*}{$\frac{\text { change }}{(-6-6)}$} & \multirow{2}{*}{$\frac{\text { pre }}{(0-6)}$} & \multirow{2}{*}{$\frac{\text { change }}{(-6-6)}$} & \multirow{2}{*}{$\frac{\text { pre }}{(0-30)}$} & \multirow{2}{*}{$\begin{array}{c}\text { change } \\
\begin{array}{c}-30- \\
30)\end{array}\end{array}$} \\
\hline & $\mathrm{N}$ & & & & & & & & & & & & \\
\hline no PI & 22 & 2.68 & .18 & 2.14 & .50 & 2.68 & .50 & 3.23 & .05 & 3.05 & .05 & 13.77 & 1.27 \\
\hline $\begin{array}{l}\mathrm{CDU} / \\
\mathrm{CSU}\end{array}$ & 51 & 3.35 & -.10 & 2.98 & -.22 & 3.69 & -.59 & 3.45 & -.55 & 2.82 & -.35 & 16.29 & -1.80 \\
\hline FDP & 4 & 3.25 & .50 & 5.25 & .25 & 4.25 & .75 & 5.00 & .00 & 4.25 & .00 & 22.00 & 1.50 \\
\hline SPD & 42 & 3.52 & -.07 & 2.40 & .17 & 3.48 & .31 & 3.40 & .19 & 2.88 & .31 & 15.69 & .90 \\
\hline $\begin{array}{l}\text { Green } \\
\text { Party }\end{array}$ & 12 & 3.17 & .50 & 3.00 & -.50 & 3.17 & .50 & 3.83 & .17 & 2.83 & .58 & 16.00 & 1.25 \\
\hline The Left & 10 & 3.00 & .30 & 2.60 & .20 & 2.30 & .60 & 2.50 & .50 & 3.50 & .70 & 13.90 & 2.30 \\
\hline other & 6 & 3.17 & .67 & 3.33 & .33 & 2.67 & .67 & 3.50 & 1.00 & 3.17 & 1.17 & 15.83 & 3.83 \\
\hline Eta & & .19 & .17 & .30 & .22 & .33 & .36 & .20 & .26 & .14 & .29 & .20 & .32 \\
\hline $\mathrm{N}$ & 147 & & & & & & & & & & & & \\
\hline
\end{tabular}


party identification and learning about the party of identification is not observed systematically across all groups of party identifiers. Indeed, H4 is only completely supported for identifiers of the Left Party as they learn more compared to nonidentifiers and also learn most about their identification party.

\section{c) Subjective knowledge gain by VAA-usage}

Table 7 displays subjective knowledge gain by VAA-usage. Respondents were asked about which political party positions they felt they had learned something in the course of using the Wahl-O-Mat. Subjectively most respondents stated they had learned most about the big German parties CDU/CSU and SPD, and least participants gained knowledge about The Left. In general the numbers are quite low, not even every seventh respondent stated to have learned something new about the CDU/CSU or the SPD. The means show that respondents on average believed they had gained new information about one issue position of CDU/CSU and about half an issue position of The Left. Overall respondents subjectively acquired knowledge on about 3.4 party positions on average, out of a total of 30 positions possible. And $42.0 \%$ of the respondents claimed not to have learned anything new about any party position at all during VAA-usage (table not shown). This corresponds to the results on objective learning, according to which $52.7 \%$ of participants showed a loss or no change in knowledge (measured as correct answers) after VAA-usage.

Table 7: Subjectively improved knowledge by Wahl-O-Mat: issues and party positions (all respondents)

\begin{tabular}{|l|r|r|c|c|c|c|c|}
\hline $\mathrm{n}=150$ quoted (percentages) & CDU/CSU & FDP & SPD & $\begin{array}{c}\text { Green } \\
\text { Party }\end{array}$ & $\begin{array}{c}\text { The } \\
\text { Left }\end{array}$ & $\begin{array}{c}\text { other } \\
\text { parties }\end{array}$ & $\begin{array}{c}\text { Countindex } \\
\text { 0-5 mean* }\end{array}$ \\
\hline minimum wage & 15.3 & 10.7 & 14.0 & 12.0 & 8.0 & 3.3 & .60 \\
\hline data retention & 16.7 & 8.7 & 15.3 & 12.0 & 8.0 & 3.1 & .61 \\
\hline $\begin{array}{l}\text { same-sex partnerships: joint ad- } \\
\text { option }\end{array}$ & 17.3 & 9.3 & 12.0 & 10.0 & 6.7 & 3.3 & .55 \\
\hline top rate income tax & 16.7 & 8.7 & 14.0 & 10.0 & 9.3 & 4.7 & .59 \\
\hline eurobonds & 15.3 & 6.0 & 10.0 & 10.0 & 8.7 & 5.1 & .50 \\
\hline gender quota & 16.0 & 8.0 & 13.3 & 12.7 & 8.0 & 3.8 & .58 \\
\hline all countindex (mean) (0-30) & .97 & .51 & .79 & .67 & .49 & .69 & 3.43 \\
\hline
\end{tabular}

* without „other parties“ 
Yet, objective learning ${ }^{16}$ does not correlate with subjective learning significantly (Pearson's $r=.08$ ). In order to analyze the distribution of self-assessment relative to objective learning, the following calculation is applied: [amount of party positions quoted as newly learned information by the respondent] - [amount of objective learning between the two points of measurement], with both indices ranging from 0 to 30. A negative value resembles a too negative self-assessment, a value of zero a correct estimation and a positive value an exaggerated self-assessment. ${ }^{17}$ The results show that the majority of participants $(54 \%)$ underestimate learning effects, while $16 \%$ have a correct impression of their learning and $30 \%$ overestimate the amount of new information they hold afterwards (table 8). For these reasons H11 is not supported empirically.

Table 8: Self-assessment of learning effects

\begin{tabular}{|l|c|c|}
\hline & percentages & N \\
\hline too negative self-assessment & 54 & 81 \\
\hline correct self-assessment & 16 & 24 \\
\hline too positive self-assessment & 30 & 45 \\
\hline all & 100 & 150 \\
\hline
\end{tabular}

\section{Conclusion}

One advantage of our survey is a sample which originates from an online-panel, and is therefore not biased by self-recruitment and correspondingly high political interest. Despite the small sample size, it offers an impression of the possible knowledge effects by using a VAA. Surely, we are not able to simulate a completely realistic pattern of VAA-use as - while our participants were of course free to decide whether and when to participate in the survey - they were not seeking for political information due to an intrinsic interest. As in the end the extend of political learning will also be dependent on the motivation and interest the user holds, this aspect of our design might have influenced individual learning outcomes in the course of our survey negatively. Furthermore we did not influence whether respondents focused their attention on the final vote advice or paid attention to the information on party positions as well, which in turn resembles the VAA-use under real-life conditions.

16 Objective learning is here operationalized as a score of the items the participants answered false or with "don't know" before VAA-usage but correctly afterwards. For reasons of comparability, here we did not use a net index of objective knowledge gain as we could not expect participants to estimate their subjective net gain in knowledge.

17 This procedure is not sensitive regarding the specific items, on which participants believed they had learned something new. 
Altogether, we find a low increase in objective knowledge on particular parties and issues after the usage of the VAA, corresponding to the findings of Schultze (2014). Learning processes are accompanied by a relatively stronger increase in the number of "don't know"-answers with the increase in right and "don't know"responses constituting the decrease in wrong answers. The rise of objective knowledge about political issues rests on merely two out of six items, while the other four show a slight decrease in knowledge. Even though a relative majority of respondents is able to achieve a net gain in correct knowledge about all parties and issues, a substantive proportion of $40 \%$ of respondents shows a loss of correct answers. Moreover, in most cases the changes only apply to one single issue position. On average respondents who learned via Wahl-O-Mat-usage did so by $33 \%$ of their design-determined learning potential. Participants who deteriorated, on average decreased by $34 \%$ of their potential for unlearning.

While holding an opinion about certain issues has an effect on knowledge about these topics, it does not steer respective learning processes. Also party identification is mostly linked to knowledge on the preferred party, but does not show a systematic effect on learning. The same applies to classical correlates of political knowledge, like socio-demographic and motivational variables. While interest in politics, education, gender and the usage of certain communication structures as sources for political information can explain pre-VAA knowledge levels, they do not correlate with overall net knowledge changes significantly and only to a small degree with the exhaustion of learning resp. unlearning potential in the context of our experimental design.

As was mentioned above the Wahl-O-Mat was designed to meet the needs of younger voters. Nevertheless, our results show that younger users are rather confused by VAA-use. Learning in the context of our design is primarily determined by pre-existing knowledge. According to the knowledge gap hypothesis individuals with a higher social status, especially with a higher educational level, should profit more from Wahl-O-Mat-information flow. However, our results indicate that the effect of socio-demographic characteristics on learning via Wahl-O-Mat is of an indirect nature, mediated by initial knowledge levels prior to Wahl-OMat-usage.

The subjective knowledge gain by Wahl-O-Mat-usage occurs mostly in respect to the bigger parties CDU and SPD. Subjective and objective knowledge gains are not significantly related.

Generally speaking, in order to achieve substantial gains in knowledge, users should turn to the VAA as their tool of choice and show a demand for knowledge. But whether the Wahl-O-Mat indeed works as an information database that people visit in order to find out the position of a certain party $\mathrm{X}$ on a specific issue $\mathrm{Y}$ is disputable. The majority of respondents underestimate learning by Wahl-O-Matutilization. This is problematic as a more optimistic perception of knowledge gain 
could motivate users and hereby encourage political learning as well as political efficacy. Learning about party positions is also hampered by the design of the Wahl-O-Mat itself. For example, there is no feature that would allow users to compare party positions on specific, self-selected issues. Users can select parties but have to scroll through all of the 38 implemented issues in order to find those of highest personal interest to them. This design choice might lead to an information overflow and lessen the motivation for searching further information.

The effects of Wahl-O-Mat-usage on information levels are very heterogeneous. Beside the supposed positive effects on political knowledge, substantial proportions of newly-created uncertainty occur. This uncertainty might lead to users being driven away by information overload on the one hand or it might show a contrary effect in mobilizing them to collect additional political knowledge on their own. Normatively spoken, knowledge about different parties' positions is at the core of a rationally correct voting decision and as previous studies found such knowledge is not nearly as widespread as one would wish for. Hence, German democratic culture is in need of a specialized information source like the Wahl-O-Mat. However, our results suggest that the Wahl-O-Mat is not yet able to unfold its potential for political education to the fullest and might benefit from additional features. As the observed low levels in knowledge improvement might be in part rooted in our experimental design, future research on knowledge effects by VAA-usage in Germany should be based on larger samples allowing for more complex methodological approaches.

\section{References}

Althaus, Scott L., 1998: Information Effects in Collective Preferences, in: American Political Science Review 92 (3), 545-558.

Alvarez, R. Michael/Levin, Ines/Mair, Peter/Trechsel, Alexander, 2014: Party preferences in the digital age: The impact of voting advice applications. in: Party Politics 20 (2), 227-236.

Andreadis, Ioannis/Wall, Matthew, 2014: The Impact of Voting Advice Applications on Vote Choice, in: Diego Garzia/Stefan Marschall (Eds.), Matching Voters with Parties and Candidates. Voting Advice Applications in a Comparative Perspective, Colchester, 115-128.

Arzheimer, Kai/Schmitt, Annette, 2014: Der ökonomische Ansatz, in: Jürgen W. Falter/Harald Schoen (Eds.), Handbuch Wahlforschung, Wiesbaden, 241-329. Ausubel, David P., 2000: The Acquisition and Retention of Knowledge: a Cognitive View, Dordrecht/Boston.

Bartels, Larry M., 1996: Uninformed Votes. Information Effects in Presidential Elections, in: American Journal of Political Science 40 (1), 194-230. 
Beck, Ulrich, 2003: Risikogesellschaft: auf dem Weg in eine andere Moderne, Frankfurt a. M.

Bennett, Stephen E., 1996: "Know-Nothings" Revisited Again, in: Political Behavior 18 (3), 219-233.

Berelson, Bernard/Lazarsfeld, Paul F./McPhee, William, 1954: Voting: A Study of Opinion Formation in a Presidential Campaign, Chicago.

Bhatti, Yosef, 2010: What would happen if we were better informed? Simulating increased knowledge in European Parliament (EP) elections, in: Representation 46 (4), 391-410.

Butler, David/Stokes, Donald E., 1969: Political Change in Britain: Forces Shaping Electoral Choice, New York.

Campbell, Angus/Converse, Philip E./Miller, Warren E./Stokes, Donald E., 1960: The American Voter, New York.

Campbell, Angus/Gurin, Gerald/Miller, Warren E., 1954: The Voter Decides, Evanston u. a.

Campbell, Donald T./Stanley, Julian C., 1966: Experimental and quasi-experimental designs for research, Chicago.

Dalton, Russel J./Wattenberg, Martin P., 2000: Parties without Partisans: Political Change in Advanced Industrial Democracies; Oxford.

Delli Carpini, Michael X./Keeter, Scott, 1996: What Americans know about politics and why it matters, New Haven.

Downs, Anthony, 1957: An Economic Theory of Democracy, New York.

Esser, Frank, 1999: Tabloidization of News. A Comparative Analyses of AngloAmerican and German Press Journalism, in: European Journal of Communication 14 (3), 291-324.

Festinger, Leon, 1989: A theory of cognitive dissonance, Stanford.

Fiske, Susan/Taylor Shelley, 1991: Social Cognition, New York.

Franklin, Mark N./Mackie, Thomas T./Valen, Henry, 1992: Electoral Change: Responses to Evolving Social and Attitudinal Structures in Western Societies, Cambridge.

Garzia, Diego, 2010: The Effects of VAAs on Users' Voting Behaviour: An Overview, in: Lorella Cedroni/Diego Garzia (Eds.), Voting Advice Applications in Europe. The State of the Art, Neapel, 13-33.

Garzia, Diego/Marschall, Stefan, 2012: Voting Advice Applications under review: the state of research, in: International Journal of Electronic Governance $5(3-4), 203-222$.

Garzia, Diego/de Angelis, Andrea/Pianzola, Joelle, 2014: The Impact of Voting Advice Applications on Electoral Participation, in: Diego Garzia/Stefan Mar- 
schall (Eds.), Matching Voters with Parties and Candidates. Voting Advice Applications in a Comparative Perspective, Colchester, 105-114.

Hagen, Lutz M., 2005: Konjunkturnachrichten, Konjunkturklima und Konjunktur, Köln.

Jerit, Jennifer/Barabas, Jason/Bolsen, Toby, 2006: Citizens, Knowledge, and the Information Environment, in: American Journal of Political Science 50 (2), 266-282.

Kepplinger, Hans Mathias/Weißbecker, Helga, 1991: Negativität als Nachrichtenideologie, in: Publizistik 36 (3), 330-342.

Kleinnijenhuis, Jan/Krouwel, Andre, 2007: The Nature and Influence of Party Profiling Websites. Paper presented at the conference Politicologenetmaal, Nijmegen, 29.-30. May 2007.

Kraft, Patrick, 2012: Correct Voting in Deutschland. Eine Analyse der Qualität individueller Wahlentscheidungen bei der Bundestagswahl 2009, in: Working Papers - Mannheimer Zentrum für Europäische Sozialforschung 148.

Kuklinski, James H./Quirk, Paul J./Jerit, Jennifer/Rich, Robert F., 2001: The Political Environment and Citizen Competence, in: American Journal of Political Science 45 (2), 410-424.

Ladner, Andreas/Felder, Gabriela/Fivaz, Jan, 2010: More than toys? A first assessment of voting advice applications in Switzerland, in: Lorella Cedroni/ Diego Garzia (Eds.), Voting Advice Applications in Europe. The State of the Art, Neapel, 91-124.

Lau, Richard R./Andersen, David J./Redlawsk, David P., 2008: An Exploration of Correct Voting in Recent U.S. Presidential Elections, in: American Journal of Political Science 52 (2), 395-411.

Lau, Richard R./Redlawsk, David P., 1997: Voting Correctly, in: The American Political Science Review 91 (3), 585-598.

Luskin, Robert C., 1990: Explaining Political Sophistication, in: Political Behavior 12 (4), 331-361.

Maier, Jürgen, 2009: Was die Bürger über Politik (nicht) wissen - und was die Massenmedien damit zu tun haben - ein Forschungsüberblick, in: Frank Marcinkowski/Barbara Pfetsch (Eds.), Politik in der Mediendemokratie (PVS Special Issue 42), Wiesbaden, 393-414.

Maier, Jürgen/Glantz, Alexander/Bathelt, Severin, 2009: Was wissen die Bürger über Politik? Zur Erforschung der politischen Kenntnisse in der Bundesrepublik Deutschland 1949 bis 2008, in: Zeitschrift für Parlamentsfragen 3, 561579 . 
Marschall, Stefan, 2005: Idee und Wirkung des Wahl-O-Mat, in: Aus Politik und Zeitgeschichte 55 (51-52), 41-46.

Marschall, Stefan. 2011: Wahlen, Wähler, Wahl-O-Mat, in: Aus Politik und Zeitgeschichte (4), 40-46.

Marschall, Stefan/Schultze, Martin, 2012: Normalisierung oder Mobilisierung? Die Auswirkungen politischer Online-Kommunikation auf die Wahlbeteiligung am Beispiel einer Internet-Applikation zur Bundestagswahl 2009, in: Politische Vierteljahresschrift 53 (3), 444-466.

Marschall, Stefan/Garzia, Diego, 2014: Voting Advice Applicatons in a Comparative Perspective: An Introduction, in: Diego Garzia/Stefan Marschall (Eds.), Matching Voters with Parties and Candidates. Voting Advice Applications in a Comparative Perspective, Colchester, 1-10.

Marschall, Stefan/Schmidt, Christian K., 2010: The Impact of Voting Indicators: The Case of the German Wahl-O-Mat, in: Lorella Cedroni/Diego Garzia (Eds.), Voting Advice Applications in Europe. The State of the Art, Napoli, 65-90.

Marschall, Stefan/Schultze, Martin, 2012: Normalisierung oder Mobilisierung? Die Auswirkungen politischer Online-Kommunikation auf die Wahlbeteiligung am Beispiel einer Internet-Applikation zur Bundestagswahl 2009, in: Politische Vierteljahresschrift 53 (3), 444-466.

Maurer, Marcus, 2009: Wissensvermittlung in der Mediendemokratie. Wie Medien und politische Akteure die Inhalte von Wahlprogrammen kommunizieren, in: Frank Marcinkowski/Barbara Pfetsch (Eds.), Politik in der Mediendemokratie, Wiesbaden, 151-173.

Mondak, Jeffery J./Anderson, Mary R., 2004: The Knowledge Gap: A Reexamination of Gender-Based Differences in Political Knowledge, in: The Journal of Politics 66 (2), 492-512.

Mykkänen, Juri/Moring, Tom, 2006: Dealigned Politics Comes of Age? The Effects of Online Candidate Selectors on Finnish Voters. Paper presented at the conference Politics on the Internet: New Forms and Media for Political Action, Tampere, 25.11.2006.

Nie, Norman/Junn, Jane/Stehlik-Barry, Kenneth, 1996: Education and Democratic Citizenship in America, Chicago.

Otto, Hans-Uwe/Kutscher, Nadia, 2004: Soziale Differenzen und informelle Bildung $m$ virtuellen Raum, in: Hans-Uwe Otto/Nadia Kutscher (Eds.), Informelle Bildung Online. Perspektiven für Bildung, Jugendarbeit und Medienpädagogik, Weinheim/München, 7-22. 
Pianzola, Joelle, 2011: The Interplay between Political Knowledge and VAA Use and its Effect on Voting Behavior. Paper presented at the conference Etmaal 2011, Amsterdam, 09.-10.6.2011.

Quiring, Oliver, 2004: Die Fernsehberichterstattung über die Arbeitslosigkeit und ihr Einfluss auf wahlrelevante Vorstellungen der Bevölkerung. Eine Zeitreihenanalyse, in: Publizistik 48 (1), 1-24.

Rudi, Tatjana, 2011: Sachthemen und politische Streitfragen, in: Hans Rattinger/ Sigrid Roßteutscher/Rüdiger Schmitt-Beck/Bernhard Weßels (Eds.), Zwischen Langeweile und Extremen: Die Bundestagswahl 2009, Baden-Baden, 179190.

Rudi, Tatjana/Schoen, Harald, 2013: Verwählt? Eine Analyse des Konzepts "korrektes Wählen" bei der Bundestagswahl 2009, in: Bernhard Wessels/Harald Schoen/Oscar W. Gabriel (Eds.), Wahlen und Wähler. Analysen aus Anlass der Bundestagswahl 2009, Wiesbaden, 407-425.

Ruusurvita, Outi/Rosema, Martin, 2009: Do online vote selectors influence electoral participation and the direction of the vote? Paper presented at the ECPR General Conference, Potsdam, 10.-12.9.2009.

Schmitt-Beck, Rüdiger/Weick, Stefan, 2001: Die dauerhafte Parteiidentifikation nur noch ein Mythos? Eine Längsschnittanalyse zur Identifikation mit politischen Parteien in West- und Ostdeutschland, in: Informationsdienst Soziale Indikatoren 26, 1-5.

Schoen, Harald, 2005: Ist Wissen auch an der Wahlurne Macht? Politische Kompetenz und Wahlverhalten, in: Siegfried Schumann/Harald Schoen (Eds.), Persönlichkeit. Eine vergessene Größe der empirischen Sozialforschung, Wiesbaden, 137-155.

Schoen, Harald/Weins, Cornelia, 2014: Der sozialpsychologische Ansatz zur Erklärung von Wahlverhalten, in: Jürgen W. Falter/Harald Schoen (Eds.), Handbuch Wahlforschung. Wiesbaden, 241-329.

Schultze, Martin, 2014: Effects of Voting Advice Applications (VAAs) on Political Knowledge about Party Positions, in: Policy \& Internet 6 (1), 46-68.

Stroh, Patrick K., 1995: Voters as Pragmatic Cognitive Misers: The Accuracy Effort Trade-off in the Candidate Evaluation Process, in: Milton Lodge/Kathleen M. McGraw (Eds.), Political Judgment, Ann Arbor, 229-228.

Taber, Charles S./Lodge, Milton, 2006: Motivated Skepticism in the Evaluation of Political Beliefs, in: American Journal of Political Science 50 (3), 755-769.

Tichenor, Philip J./Donohue, George A./Olien, Clarice N., 1970: Mass Media Flow and Differential Growth in Knowledge, in: The Public Opinion Quarterly 34 (2), 159-170. 
Toffler, Alvin, 1971: Future shock, New York.

Van de Pol, Jasper/Holleman, Bregje/Kamoen, Naomi/Krouwel, André/de Vreese, Claes, 2014: Beyond Young, Highly Educated Males: A Typology of VAA Users, in: Journal of Information Technology \& Politics 11 (4), 397-411 (accessible via http://dx.doi.org/10.1080/19331681.2014.958794).

Vetter, Angelika/Maier, Jürgen, 2005: Mittendrin statt nur dabei? Politisches

Wissen, politisches Interesse und politisches Kompetenzgefühl in Deutschland, 1994-2002, in: Oscar W. Gabriel/Jürgen W. Falter/Hans Rattinger (Eds.), Wächst zusammen, was zusammengehört? Stabilität und Wandel politischer Einstellungen im wiedervereinigten Deutschland. Baden-Baden, 51-90.

Walgrave, Stefaan/Nuytemans, Michiel/Pepermans, Koen, 2009: Voting Aid Applications and the Effect of Statement Selection, in: West European Politics 32 (6), 1161-1180.

Walgrave, Stefaan/van Aelst, Peter/Nuytemans, Michiel, 2008: "Do the Vote Test": The Electoral Effects of a Popular Vote Advice Application at the 2004 Belgian Elections, in: Acta Politica 43 (1), 50-70.

Wall, Matthew/Krouwel, Andre/Vitiello, Thomas, 2014: Do voters follow the recommendations of voter advice application websites? A study of the effects of kieskompas.nl on its users' vote choices in the 2010 Dutch legislative elections, in: Party Politics 20 (3), 416-428.

Westle, Bettina, 2005: Politisches Wissen und Wahlen, in: Jürgen W. Falter/ Oscar W. Gabriel/Bernhard Weßels (Eds.), Wahlen und Wähler. Analysen aus Anlass der Bundestagswahl 2002, Wiesbaden, 484-512.

Westle, Bettina, 2009 a: Politisches Wissen als Grundlage der Entscheidung bei der Bundestagswahl 2005, in: Steffen Kühnel/Oskar Niedermayer/Bettina Westle (Eds.), Wähler in Deutschland, sozialer und politischer Wandel, Gender und Wahlverhalten, Wiesbaden, 366-398.

Westle, Bettina, 2009 b: "Die unpolitische Frau" - Ein Methodenartefakt der Umfrageforschung?, in: Hannah Kaspar/Harald Schoen/Siegfried Schumann/ Jürgen R. Winkler (Eds.), Politik - Wissenschaft - Medien. Festschrift für Jürgen W. Falter zum 65. Geburstag, Wiesbaden, 179-201.

Westle, Bettina, 2011: Politisches Wissen in Deutschland. Ein Vergleich von Bürgern mit türkischem Migrationshintergrund und einheimischen Deutschen, in: Zeitschrift für Parlamentsfragen 42 (4), 835-850.

Westle, Bettina, 2012: Souveräne Teilhabe unter Unsicherheit und Halbwissen: Politisches Wissen und politische Partizipation, in: Stephan Braun/Alexander Geisler (Eds.), Die verstimmte Demokratie. Moderne Volksherrschaft zwischen Aufbruch und Frustration, Wiesbaden, 51-68. 
Address:

Prof. Dr. Bettina Westle | Dipl. Soz. Christian Begemann | Astrid Rütter, M.A. Soz.

Institut für Politikwissenschaft

Philipps-Universität Marburg

Wilhelm-Röpke-Str. 6G

35032 Marburg

E-Mail: westle@staff.uni-marburg.de | christian.begemann@staff.unimarburg.de | astrid.ruetter@staff.uni-marburg.de 


\section{Appendix}

\section{Figure A1: Structure and formulation of issue knowledge items}

\begin{tabular}{|c|c|c|c|}
\hline $\begin{array}{l}\text { The following questions deal with oppositional opin- } \\
\text { ions concerning political goals. } \\
\text { Please indicate which opinion you have personally } \\
\text { and which positions are represented by the parties. }\end{array}$ & $\begin{array}{l}\text { respondent's } \\
\text { position } \\
\text { 5-point-scale + } \\
\text { don't know: } \\
\text { (1) very much } \\
\text { opposed } \\
\text { (2) rather op- } \\
\text { posed } \\
\text { (3) indifferent/ } \\
\text { undecided } \\
\text { (4) rather in fa- } \\
\text { vour } \\
\text { (5) very much in } \\
\text { favor } \\
\text { don't know }\end{array}$ & $\begin{array}{l}\text { respondent's } \\
\text { position } \\
\text { 3-point-scale } \\
\text { + don't know: } \\
\text { (1) rather op- } \\
\text { posed } \\
\text { (2) rather in } \\
\text { favour } \\
\text { (3) undecided } \\
\text { don't know }\end{array}$ & $\begin{array}{l}\text { parties' posi- } \\
\text { tions } \\
\text { 3-point scale + } \\
\text { don't know: } \\
\text { [...] What } \\
\text { about the } \\
\text { CDU/CSU/ } \\
\text { SPD/ } \\
\text { Alliance 90, } \\
\text { The } \\
\text { Greens/The } \\
\text { Left? } \\
\text { (1) rather op- } \\
\text { posed to } \\
\text { (2) rather in } \\
\text { favour } \\
\text { (3) no clear } \\
\text { position } \\
\text { don't know }\end{array}$ \\
\hline $\begin{array}{l}1 \text { a) First of all we deal with the statutory implementation } \\
\text { of a general minimum wage. Are you personally opposed } \\
\text { to or in favour of such a general minimum wage? }\end{array}$ & $\mathrm{x}$ & & \\
\hline $\begin{array}{l}1 \mathrm{~b} \text { ) And, what do you think: How/What are the positions } \\
\text { of the parties in regard to the implementation of a sta- } \\
\text { tutory minimum wage? }\end{array}$ & & & $\mathrm{x}$ \\
\hline $\begin{array}{l}2 \text { a) Now we are talking about retention of telecommuni- } \\
\text { cation data. It deals with the comprehensive storage of } \\
\text { telecommunication data for a certain period and without } \\
\text { precise inducement. In the political debate it is discussed } \\
\text { whether this should be put into practice in Germany or if } \\
\text { it should be prohibited. Are you personally opposed to or } \\
\text { in favour of data retention? }\end{array}$ & $\mathrm{x}$ & & \\
\hline $\begin{array}{l}2 \mathrm{~b}) \text { (And what about the parties?) Are they in favour of } \\
\text { or opposed to data retention or is their position unclear? }\end{array}$ & & & $x$ \\
\hline $\begin{array}{l}3 \text { a) Now we are dealing with the legal equalization of } \\
\text { homosexual civil partnerships with marriage. Some par- } \\
\text { ties are in favour of treating those partnerships equal to } \\
\text { traditional marriages, also in terms of adoption law. } \\
\text { Others oppose this. Are you personally in favour of or } \\
\text { opposed to putting homosexual civil partnerships on a } \\
\text { par with marriage concerning adoption law? }\end{array}$ & $x$ & & \\
\hline
\end{tabular}

18 Questions in italics were repeated after VAA-usage. Wordings in brackets were not included in the repetition. 


\section{Bettina Westle, Christian Begemann and Astrid Rütter}

\begin{tabular}{|c|c|c|c|}
\hline $\begin{array}{l}3 \mathrm{~b}) \text { (And what is the deal with the parties?) Are they ra- } \\
\text { ther in favor or opposed? }\end{array}$ & & & $\mathrm{x}$ \\
\hline $\begin{array}{l}4 \text { a) Some parties want to increase the top rate of income } \\
\text { tax, others reject this. What do you personally think? Are } \\
\text { you opposed to or in favour of the increase of the top rate } \\
\text { of income tax? }\end{array}$ & $\mathrm{x}$ & & \\
\hline $\begin{array}{l}4 \mathrm{~b}) \text { (And what do you think,) what are the positions of } \\
\text { the parties concerning an increase of the top rate of in- } \\
\text { come tax? }\end{array}$ & & & $\mathrm{x}$ \\
\hline $\begin{array}{l}5 \text { a) In order to tackle the European financial crisis, some } \\
\text { parties demand the implementation of so called Euro- } \\
\text { bonds. In this case EU-states would take out a loan at the } \\
\text { capital market together and repay it conjointly. Other } \\
\text { parties oppose this idea. What do you personally think? } \\
\text { Are you in favour of or opposed to Eurobonds? }\end{array}$ & & $\mathrm{x}$ & \\
\hline $\begin{array}{l}5 \mathrm{~b}) \text { (And what do you think,) what are the positions of } \\
\text { the parties concerning Eurobonds? }\end{array}$ & & & $\mathrm{x}$ \\
\hline $\begin{array}{l}6 \text { a) In order to achieve equal opportunities for women, } \\
\text { some parties demand the introduction of a compulsory } \\
\text { quota for women's representation at the management le- } \\
\text { vel of larger companies, other oppose it. What do you } \\
\text { personally think? Are you opposed to or in favour of a } \\
\text { gender quota? }\end{array}$ & & $x$ & \\
\hline $\begin{array}{l}6 \mathrm{~b}) \text { (And what do you think:) What are the positions of } \\
\text { parties in regard to the gender quota? }\end{array}$ & & & $\mathrm{x}$ \\
\hline
\end{tabular}

\section{Figure A2}

\begin{tabular}{|l|}
\hline Wahl-O-Mat Issue-Statements \\
\hline A statutory comprehensive minimum wage should be implemented. \\
\hline The top rate of income tax should be increased. \\
\hline There should be a statutory quota for women's representation in the directorate and management of companies. \\
\hline In the Euro-Zone every state should be liable for its depts by itself. \\
\hline Also registered same-sex partnerships should have a right to joint adoption. \\
\hline No retention of communication data (e.g. telephone, internet) without concrete inducement! \\
\hline response options (for users and parties): agree, neutral, disagree; skip thesis \\
\hline
\end{tabular}

\section{Figure A3}

\begin{tabular}{|l|c|c|c|c|c|}
\hline $\begin{array}{l}\text { Correct answers according to Wahl-O- } \\
\text { Mat }\end{array}$ & CDU/CSU & FDP & SPD & $\begin{array}{c}\text { Green Par- } \\
\text { ty }\end{array}$ & The Left \\
\hline Minimum wage & against & against & for & for & for \\
\hline Retention of communication data & for & against & for & against & against \\
\hline
\end{tabular}


The "Wahl-O-Mat" in the course of the German Federal Election 2013

\begin{tabular}{|l|c|c|c|c|c|}
\hline Same-sex partnerships: joint adoption & against & for & for & for & for \\
\hline Top rate income tax & against & against & for & for & for \\
\hline Eurobonds & against & against & $\begin{array}{c}\text { no clear } \\
\text { pos. }\end{array}$ & for & for \\
\hline Quota for women's representation & $\begin{array}{c}\text { no clear } \\
\text { pos. }\end{array}$ & against & for & for & for \\
\hline
\end{tabular}

\section{Table A1}

\begin{tabular}{|c|c|c|c|}
\hline \multicolumn{3}{|c|}{$\begin{array}{l}\text { Sample: Demographic parameters and political attitudes (percentages, } \\
\text { means) }\end{array}$} & \multirow{2}{*}{\begin{tabular}{|c|} 
(N)Onliner-Atlas 2013 \\
52.2 \\
47.8
\end{tabular}} \\
\hline gender & $\begin{array}{l}\text { males } \\
\text { females }\end{array}$ & $\begin{array}{l}55.0 \\
45.0\end{array}$ & \\
\hline age & \begin{tabular}{|l}
$18-29$ \\
$30-39$ \\
$40-49$ \\
$50-59$ \\
$60-69$ \\
$70+$
\end{tabular} & $\begin{array}{r}22.1 \\
18.8 \\
26.2 \\
18.1 \\
11.4 \\
3.4\end{array}$ & $\begin{array}{c}21.9 \\
18.1 \\
23.4 \\
18.0 \\
11.4 \\
7.1\end{array}$ \\
\hline $\begin{array}{l}\text { region of resi- } \\
\text { dence }\end{array}$ & $\begin{array}{l}\text { west } \\
\text { east (including Berlin) }\end{array}$ & $\begin{array}{l}79.9 \\
20.1\end{array}$ & $\begin{array}{l}80.1 \\
19.9\end{array}$ \\
\hline $\begin{array}{l}\text { formal education } \\
\text { level }\end{array}$ & $\begin{array}{l}\text { no school-leaving qualification } \\
\text { general secondary education } \\
\text { intermediate secondary education } \\
\text { upper secondary education }\end{array}$ & $\begin{array}{r}0.7 \\
19.6 \\
43.2 \\
36.5\end{array}$ & $\begin{array}{r}- \\
31.7 \\
32.0 \\
33.3\end{array}$ \\
\hline $\begin{array}{l}\text { monthly net inco- } \\
\text { me of household }\end{array}$ & $\begin{array}{l}\text { less than } 2.600 \text { Euro } \\
2.601-\text { less than } 4.500 \text { Euro } \\
4.500 \text { Euro and more }\end{array}$ & $\begin{array}{l}51.5 \\
36.7 \\
11.8\end{array}$ & $\begin{array}{l}\text { less than } 2.500: 45.8 \\
\text { to less than } 4.000: 35.2 \\
\text { more than 4.000: } 6.4\end{array}$ \\
\hline \multirow[t]{2}{*}{ interest in politics } & & & $\begin{array}{l}\text { GLES } 2013 \text { online pre-elec- } \\
\text { tion study (weighted results) }\end{array}$ \\
\hline & $1=$ not at all to $5=$ very much: mean & 3.3 & 3.3 \\
\hline $\begin{array}{l}\text { party identificati- } \\
\text { on (pi) }\end{array}$ & $\begin{array}{l}\text { none } \\
\text { CDU (Christian Democratic Union) } \\
\text { SPD (Social Democratic Party) } \\
\text { FDP (Free Democratic Party) } \\
\text { Alliance '90/The Green Party } \\
\text { The Left } \\
\text { Pirate Party } \\
\text { NPD (National Democratic Party) } \\
\text { other party }\end{array}$ & $\begin{array}{r}15.0 \\
34.7 \\
28.6 \\
2.7 \\
8.2 \\
6.8 \\
0.7 \\
0.7 \\
2.7\end{array}$ & $\begin{array}{r}18.3 \\
27.8 \\
27.0 \\
1.8 \\
12.3 \\
4.6 \\
1.8 \\
- \\
1.1\end{array}$ \\
\hline intensity of pi & $1=$ very low to $5=$ very strong: mean & 3.6 & 3.7 \\
\hline$N$ & & 150 & 1.028 \\
\hline
\end{tabular}




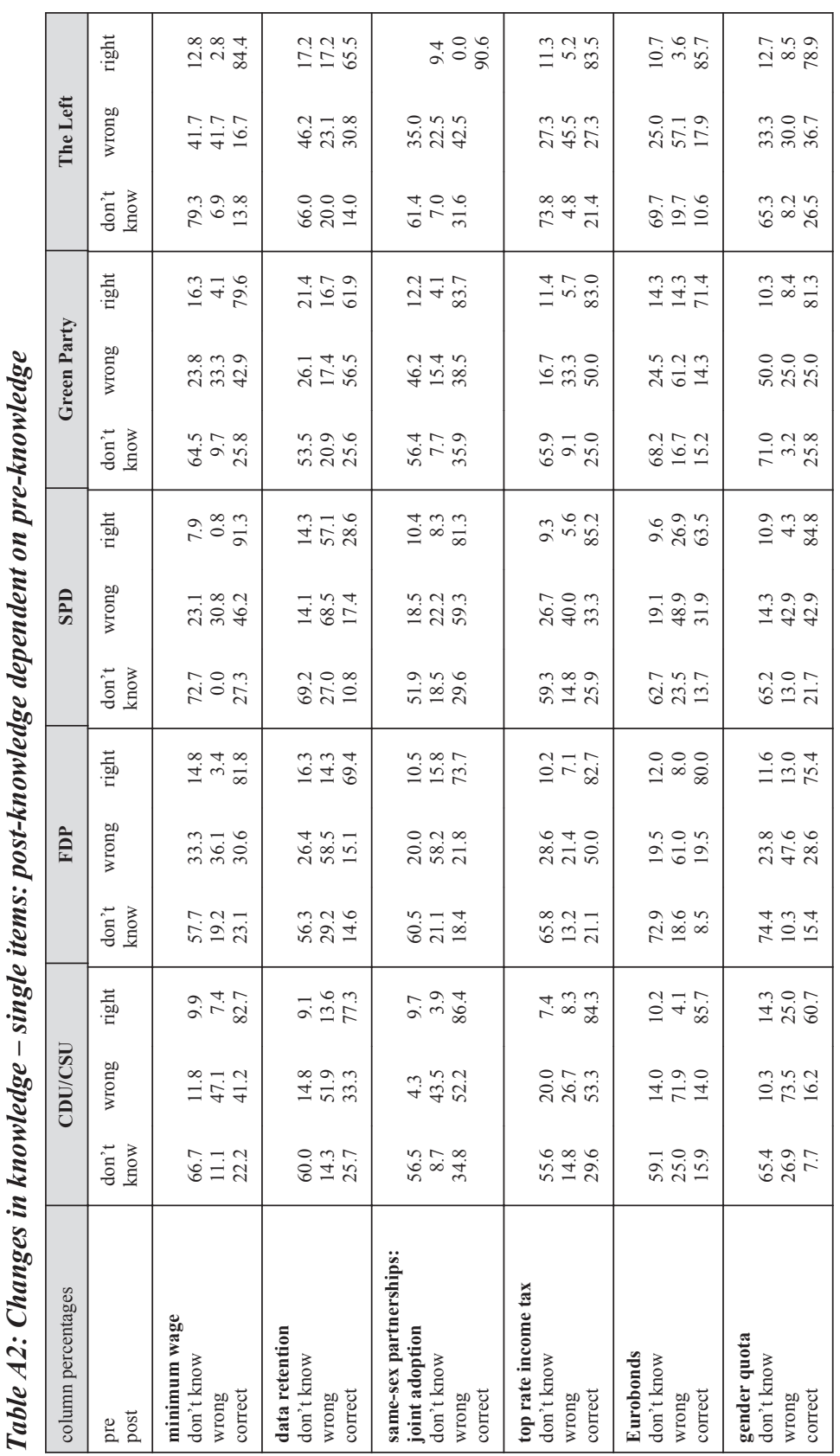

